\title{
Postharvest quality of Aster ericoides after treatment with silver thiosulphate and sucrose
}

\section{Kathia Fernandes Lopes Pivetta ${ }^{1}$ Claudia Fabrino Machado Mattiuz ${ }^{2 *} \odot$ Regina Ferreira de Melo ${ }^{1}$ Renata Gimenes ${ }^{1}$ Gustavo de Nobrega Romani ${ }^{1}$ Gisele Sales Batista ${ }^{1}$}

${ }^{1}$ Departamento de Produção Vegetal, Faculdade de Ciências Agrárias e Veterinárias (FCAV), Universidade Estadual Paulista (UNESP), Jaboticabal, SP, Brasil.

${ }^{2}$ Departamento de Produção Vegetal, Escola Superior de Agricultura Luiz de Queiroz (ESALQ), Universidade de São Paulo (USP), 13418-900, Piracicaba, SP, Brasil. E-mail: cmattiuz@gmail.com. "Corresponding author.

\begin{abstract}
Aster (Aster ericoides L.) is a flower crop of North American origin, which belongs to the family Asteraceae. This plant presents capitulum-type inflorescences, widely used as cut flowers. In Brazil, it has been grown only recently, but still has a high expansion potential. In floriculture, pulsing and conditioning solutions are often used to extend the vase life of cut flowers. The present study aimed to evaluate the influence of silver thiosulphate (STS) pulsing and sucrose solutions on the postharvest life of A. ericoides stems. The experiment was carried out under a complete randomized design with treatments arranged in a $2 \times 5$ factorial scheme. Treatments consisted of flower stems treated with STS pulsing for 30 minutes, combined with four sucrose concentrations $(5,10,15$, and 20\%) for six hours, plus a control (without treatment). Each plot contained four replicates of 10 stems, totalizing 400 stems. The following variables were daily: vase life, fresh mass, and relative water content $(R W C)$. For pulsing data, means were compared by the Tukey's test ( $p \geq 5 \%)$. Yet for sucrose concentrations, means were submitted to a polynomial regression to verify the behavior of variables as a function of concentrations increases. Likewise, each treatment was evaluated for fresh mass and RWC variations over time by a polynomial regression. Results indicated no effect of STS pulsing (2mM) on the vase-life length of aster stems. In contrast, the sucrose solution at 10\% extended the vase life of stems by two days, decreased fresh mass loss, and helped maintain water balance in stems.
\end{abstract}

Key words: water relations, vase life, pulsing, aster.

\section{Qualidade pós-colheita de Aster ericoides após tratamento} com tiossulfato de prata e sacarose

RESUMO: $O$ áster (Aster ericoides L.) é originário da América do Norte, pertence à família Asteraceae, possui inflorescências do tipo capítulo e é muito usada como flor de corte. No Brasil, sua produção é recente e apresenta grande potencial de expansão. O uso de soluções de "pulsing" e de acondicionamento, em flores de corte, é bastante empregado na floricultura para prolongar o tempo de prateleira. O objetivo do presente estudo foi avaliar a influência do "pulsing" de STS (tiossulfato de prata) e do condicionamento em soluções de sacarose na vida pós-colheita de hastes de A. ericoides. $O$ delineamento experimental foi inteiramente casualizado e os tratamentos foram arranjados em esquema fatorial 2x5, ou seja, com e sem aplicação de "pulsing" com tiossulfato de prata (STS) 2 mM por 30 minutos, combinados com quatro concentrações de sacarose: 5, 10, 15 e 20\% por 6 horas e tratamento controle; foram 4 repetições e 10 hastes por parcela, perfazendo um total de 400 hastes. Avaliou-se diariamente a vida de vaso, acúmulo de massa fresca e conteúdo relativo de água (CRA) das hastes tratadas. Os dados de "pulsing" (STS) as médias foram comparadas pelo Teste de Tukey a 5\% de probabilidade. As médias de sacarose foram submetidas à análise de regressão polinomial a fim de verificar o comportamento das variáveis em função do aumento da concentração de sacarose e para massa fresca e CRA foi realizada regressão polinomial para cada tratamento a fim de verificar o comportamento do tratamento ao longo do tempo. Concluiu-se que tratamento de "pulsing" com tiossulfato de prata (STS) a 2 mM por 30 minutos não contribuiu para o aumento da vida de vaso das hastes de áster. O tratamento de condicionamento com 10\% de sacarose prolongou a vida de vaso em dois dias, diminuiu a perda de massa fresca e favoreceu o balanço hídrico de hastes de áster. Palavras-chave: relações hídricas, vida de vaso, pulsing, áster.

\section{INTRODUCTION}

Aster (Aster ericoides L.) is a semiperennial and herbaceous plant originated in North America and belongs to the Asteraceae family. This flower has daisy-like inflorescences arising on the tips of branches (LARSON, 1980). It has been widely used to compose floral arrangements since its light and small capitulumtype flowers create delicate ornaments. Depending on the cultivar, flowers may be white, pink, and lavender colors; however, Brazilian florists still 
prefer white ligules. Aster has been grown for cut flower purposes in Brazil only recently, with its cultivation expanding in the nineties and now among the most cultivated species in São Paulo State - Brazil (JUNQUEIRA \& PEETZ, 2015).

Loss of post-harvest decorative life in flowers may be caused by several factors such as microbial action, turgor loss, ethylene action and senescence (VAN MEETEREN, 2009). However, some techniques can be used in postharvest to increase vase life by maintaining quality of cut flowers (REID \& JIANG, 2012).

A fast method for transport and stock of cut flowers consists of treating stems with pulsing solutions, thus the ornamental quality of flowers could be maintained for longer after harvest. Several chemical compounds can be used in these pulsing solutions, and the results vary with species and treatment duration (SRILAONG \& BUANONG, 2007).

Although, A. ericoides cultivation has recently increased, few studies are reported for this species, especially regarding postharvest physiology and technology. Therefore, the present research had the objective of evaluating the influence of silver thiosulphate and sucrose solution on the vase life of $A$. ericoides L. stems.

\section{MATERIALS AND METHODS}

White-flowered Aster ericoides L. stems were purchased from a commercial grower in Paraíso city, São Paulo State (Brazil), in July 2012. These flowers were transported in a refrigerated vehicle to the Laboratory of Horticultural and Forestry Seeds, Faculdade de Ciências Agrárias e Veterinárias (FCAV)-Universidade Estadual Paulista (UNESP), in Jaboticabal city, São Paulo State (Brazil). In the laboratory, stems were sorted for flower quality, growth stage, and length $(0.80 \mathrm{~m})$. Of these, half were pulsed with silver thiosulphate - STS (2mM) for 30 minutes. Later, both pulsed and non-pulsed stems were placed in conditioning solutions at different sucrose concentrations $(0,5$, 10,15 , and $20 \%$ ) for six hours. Then, they were transferred to distilled water in 500-mL Erlenmeyer flasks, which were kept in a room at $20-24^{\circ} \mathrm{C}, 61-$ $69 \% \mathrm{RH}$, and under continuous lighting for 11 days. Vase water contents were changed every day, as well as were vase life analysis.

The experiment was carried out in a fully randomized design, arranged in a $2 \times 5$ factorial scheme. The factors consisted of two pulsing treatments (STS-pulsed and control-non-pulsed) and five sucrose solution concentrations $(0,5,10,15$, and 20\%). Each plot had four replications with 10 stems each, totalizing 400 stems. Vase life was considered when $50 \%$ or more inflorescences per stem had lost ornamental value. Each plot was counted for days of vase life, which was the average life of stems, expressed in days. After 3, 5, 7, 9, and 11 days of cutting, the stems were weighed for fresh mass measurement, and relative water content (RWC) was determined.

The RWC was estimated as described by KRAMER (1983), using 10 ligules of each capitulum per plot. This method consisted of immediately after weighing samples for fresh mass (FM) and then soak them in distilled water for four hours. After being weighed wet, excess water was removed using a plastic sieve and again weighed for turgid mass determination (TM). Finally, they were dried in a forced-air oven at $70^{\circ} \mathrm{C}$ to determine dry mass (DM). The RWC was calculated using the following equation: RWC = $($ FM-DM $) /($ TM-DM $) \times 100$.

Data were expressed in percentage and transformed to arcsine (x/100) $1 / 2$ for statistical analysis. For STS pulsing, the means were compared by the Tukey's test $(\mathrm{p} \geq 5 \%)$, and for sucrose concentrations, a polynomial regression was used to verify the behavior of variables as a function of concentration increase. Likewise, each treatment was evaluated for fresh mass and RWC variations over time by a polynomial regression.

\section{RESULTS AND DISCUSSION}

Pulsing treatments showed no significant differences until 7.3 days of vase life. However, the sucrose concentration providing the longest vase life was $10 \%$ (Figure 1). Sucrose is one of the main components of conditioning solutions, and vase-life prolongations have been attributed to the ability of this disaccharide in maintaining water relations and stimulating anthesis in treated plants (FINGER et al., 2004; SINGH et al., 2009).

On average, inflorescence longevity was seven days; however, when conditioned with $10 \%$ sucrose for six hours, it reached nine days, thus prolonging the vase life of aster stems. This might have been due to beneficial effects of sucrose (HALEVY \& MAYAK, 1979; VAN DOORN, 2001), such as a balance of water relations and delay in ethylene synthesis (VAN MEETEREN, 2009). 


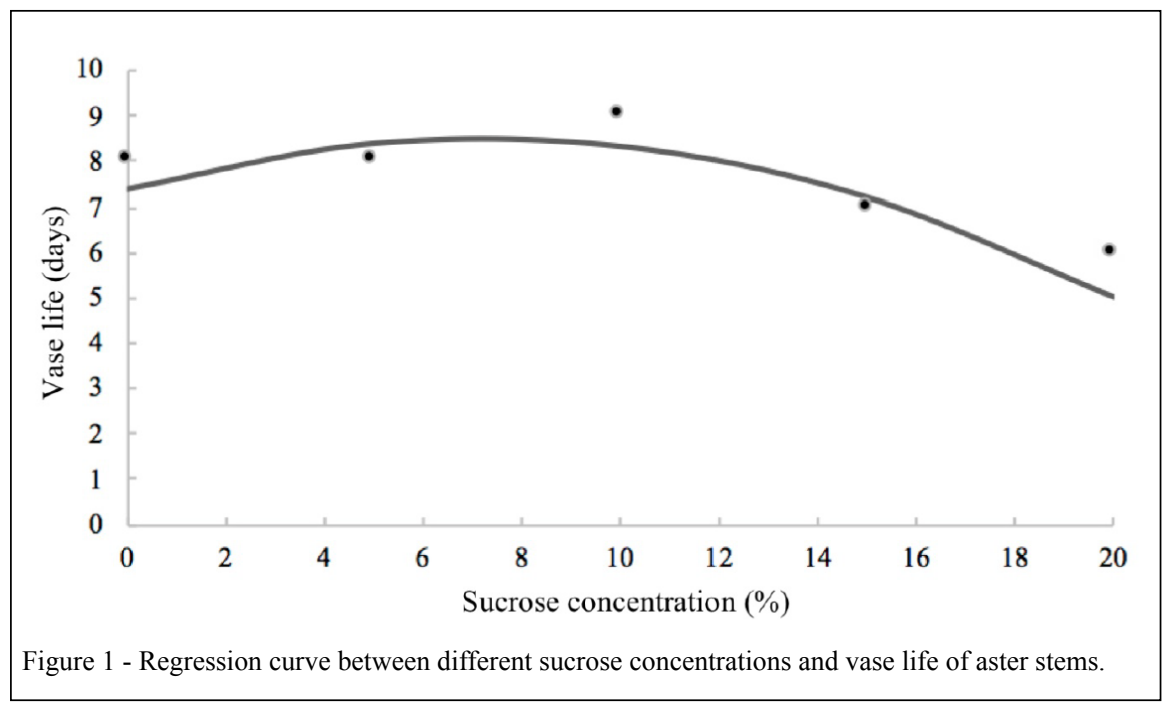

Moreover, sucrose acts as a respiratory substrate, replacing the natural sugars consumed soon after harvest (VAN DOORN, 2001). For many other cut flowers with many flower buds, treatments with sugars have shown to promote flower opening and extend vase life (HALEVY \& MAYAK, 1979; PUN \& ICHIMURA, 2003). Despite the beneficial effects and efficiency of sucrose solutions, negative responses have been reported on the longevity of some cut-flower species when treated with high concentrations (HAN, 1998).

Pulsing with STS (2mM) for 30 minutes was ineffective to increase vase life of aster stems. The silver ion $\left(\mathrm{Ag}^{+}\right)$is known to be able to increase vase life of cut stems since it acts as a competitive inhibitor of ethylene, as explained by COOK \& VAN STADEN (1987). However, each species might show different responses to the treatments; this might occur due to both intrinsic factors such as enzyme binding to ethylene receptor sites, or extrinsic ones such as STS concentration and storage conditions. According to REID et al. (1980), for the STS pulsing to be efficient as an anti-ethylene agent, treatment should last long enough to increase STS accumulation in petal tissues.

All treatments presented a linear negative adjustment for stem fresh mass, and the conditioning treatment with $10 \%$ sucrose led to minor changes in fresh mass (Figure 2A). For VAN DOORN (2001), water uptake capacity can be improved by a mechanism whereby sugar is accumulated in flower petals, what favors their turgor maintenance by increasing osmotic pressure.

All treatments showed a decrease in RWC during post-harvest (Figure 2B). Turgor should be maintained until full maturity for development of floral buds. Wilting can be either a normal physiological process part of natural senescence or a consequence of vascular occlusion by microorganisms (VAN DOORN, 1999). However, the absence of sucrose increased RWC reduction; therefore, only water was unable to maintain hydric balance during the vase life of stems. In terms of water status (RWC), STS pulsing treatment was significantly higher than control in all evaluated days (Table 1). Furthermore, sucrose concentrations differed from each other in all evaluations with a quadratic regression fit (Figure 3), thus sucrose was efficient to maintain RWC in inflorescences.

In short, both STS and sucrose were effective in maintaining the quality of aster stems, due to the greater turgor observed in them. These results could be explained in light of the floral organ turgor result from a balance between its tendency to lose water, by transpiration, and its capacity to drive water into the cells. For this reason, the greater the flower turgor, the better are the conditions to maintain metabolic activity and increase longevity. REID (2012) emphasizes that, since simple sugars are the main component of floral preservative solutions, they may act as regulators of water relations, thus promoting flower development and increasing vase life.

Ciência Rural, v.48, n.12, 2018. 


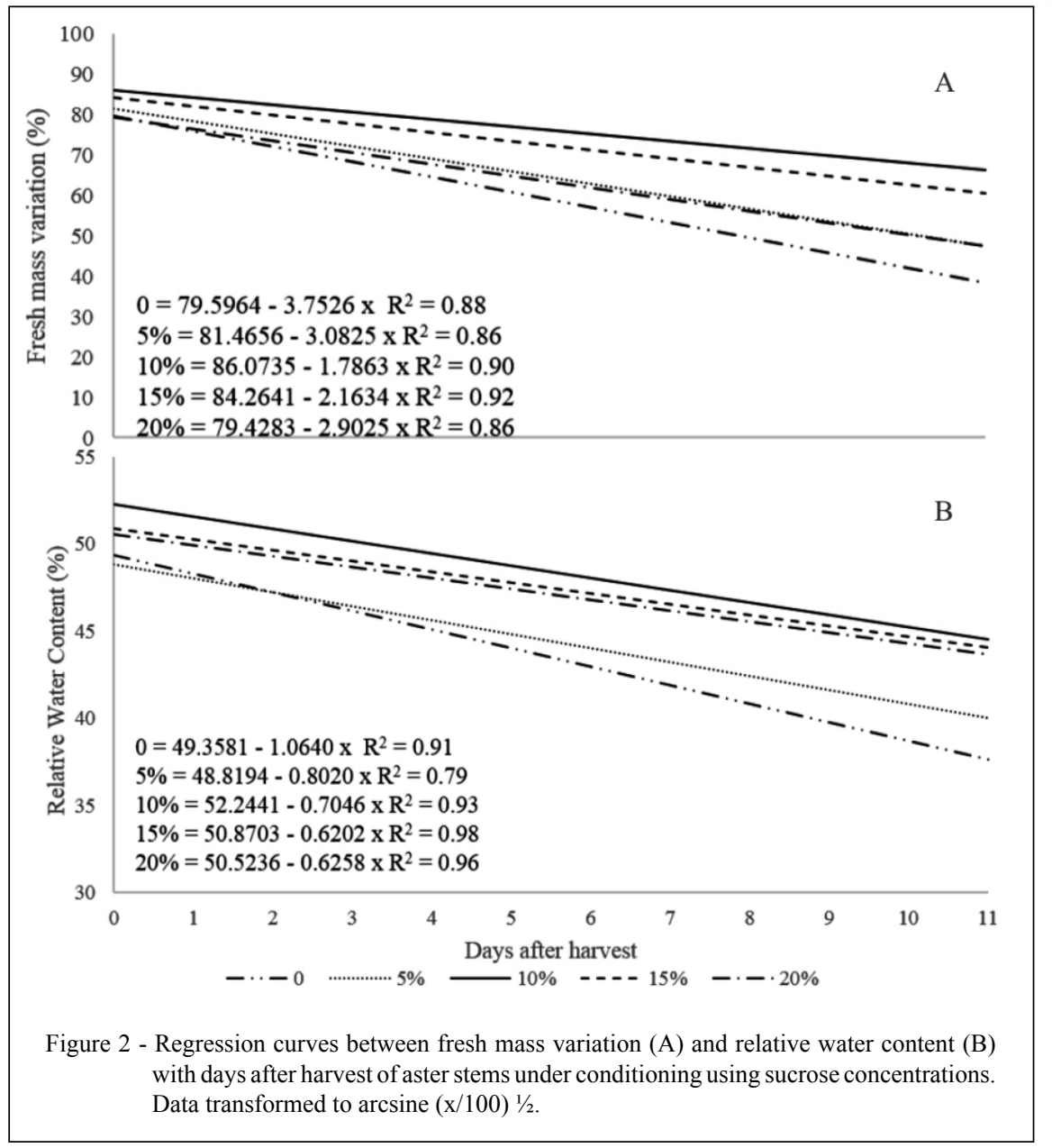

\section{CONCLUSION}

Silver thiosulphate pulsing at $2 \mathrm{mM}$ for 30 minutes had no contribution to the longevity of aster stems. Conversely, sucrose solutions at
$10 \%$ enabled longer vase life, on average two days more than the other treatments. Besides, sucrose treatment improved cut-flower quality, as it decreased fresh weight losses and favored water balance.

Table 1 - Relative water content (\%) in aster stems submitted or not to silver thiosulphate (STS) pulsing and conditioning at different sucrose concentrations $(0,5,10,15$, and $20 \%)$ in five evaluation days.

\begin{tabular}{|c|c|c|c|c|c|}
\hline & 3 days & 5 days & 7 days & 9 days & 11 days \\
\hline With pulsing & $55.6 \mathrm{a}$ & $54.4 \mathrm{a}$ & $53.2 \mathrm{a}$ & $50.8 \mathrm{a}$ & $48.3 \mathrm{a}$ \\
\hline Without pulsing & $53.6 \mathrm{~b}$ & $52.0 \mathrm{~b}$ & $50.3 \mathrm{~b}$ & $47.7 \mathrm{~b}$ & $45.1 \mathrm{~b}$ \\
\hline
\end{tabular}

*Means followed by different letters in the column differ statistically by the Tukey’s test $(\mathrm{P}<0.05)$.

Ciência Rural, v.48, n.12, 2018. 


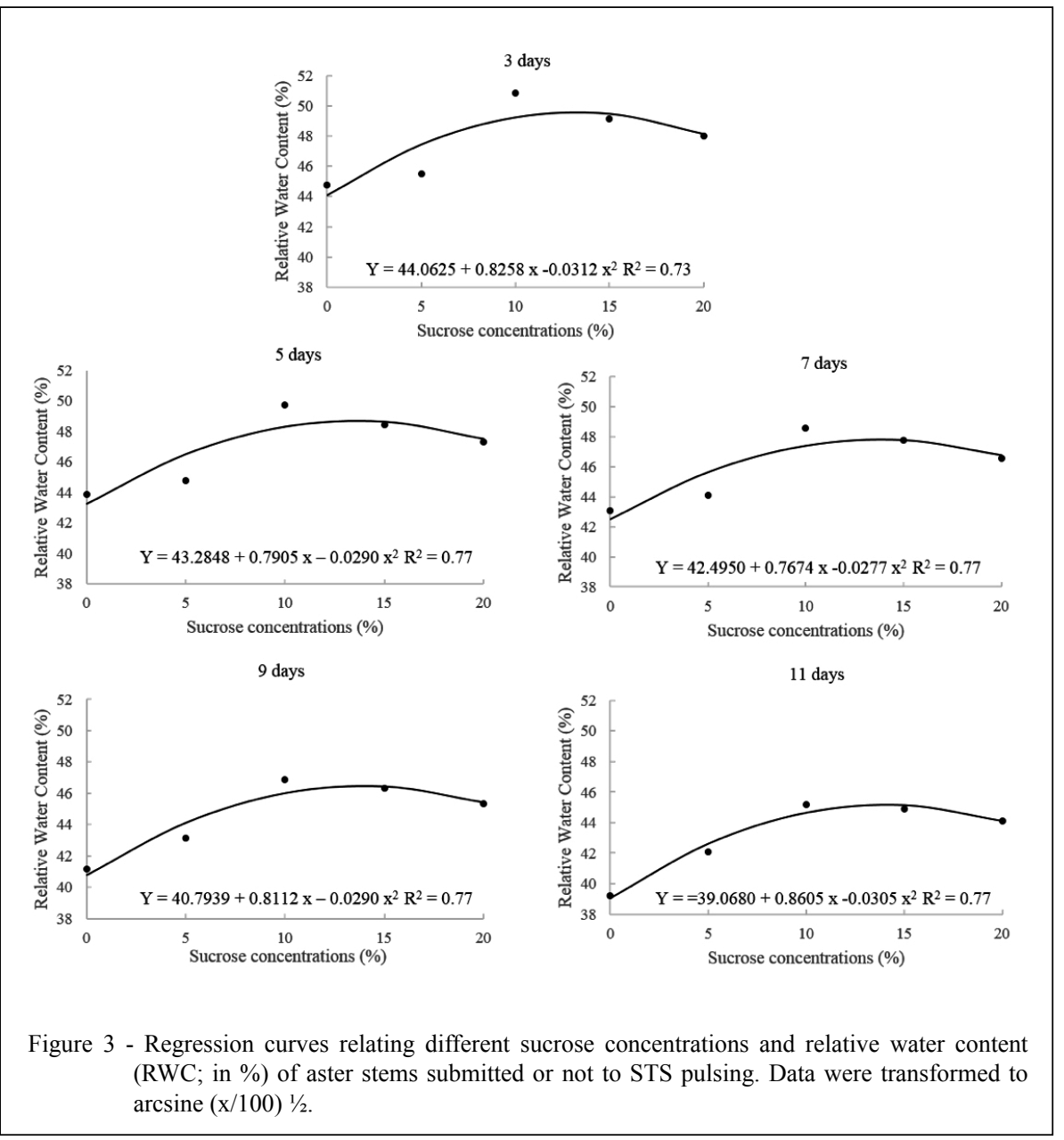

\section{DECLARATION OF CONFLICTING INTERESTS}

The authors declare no conflict of interest. The founding sponsors had no role in the design of the study; in the collection, analyses, or interpretation of data; in the writing of the manuscript, and in the decision to publish the results.

\section{REFERENCES}

COOK, E.L.; VAN STANDEN, J. Silver action in the cut carnation flower. Plant Physiology Biochemistry, v.25, p.485-492, 1987.

FINGER, F.L. et al. Postharvest senescence of Consolida ajacis inflorescences (Consolida ajacis). Pesquisa Agropecuária Brasileira, v.39, p.533-537, 2004. Available from: <http://dx.doi. org/10.1590/S0100-204X2004000600003>. Accessed: Jun. 05, 2017. doi: 10.1590/S0100-204X2004000600003.

HALEVY, A.H.; MAYAK, S. Senescence and postharvest physiology of cut flowers. Horticultural Reviews, v.1, p.204236,1979 .
HAN, S. S. Postharvest handling of cut Heuchera sanguinea Engelm. Flowers: Effects of sucrose and silver thiosulfate. HortScience, v.33, p.731-733, 1998.

JUNQUEIRA, A.H.; PEETZ, M.S. Flores e Plantas Ornamentais do Brasil, 2015. Série Estudos Mercadológicos. Brasília: SEBRAE. Available from: $<$ http://hortica.com.br/artigos/>. Accessed: Mar. 12, 2016.

KRAMER, P.J. Water Relations of Plants, New York: Academic Press, 1983, 482p.

LARSON, R. A. Introduction to floriculture, New York: Academic Press, 1980, 608p.

PUN, U.K., ICHIMURA, K. Role of sugars in senescence and biosynthesis of ethylene in cut flowers. Japan Agricultural Research Quarterly, v.37, p.219-224, 2003.

REID, M.S.; et al. Pulse treatments with silver thiosulfate complex extend the vase life of cut carnations. Journal American Society Horticultural Science, v.105, p.25-27, 1980. 
REID, M.S.; JIANG, C. Postharvest biology and technology of cut flowers and potted plants. Horticultural Reviews, v.40, p.1-54, 2012.

SINGH, A.; et al. Influence of sucrose pulsing and sucrose in vase solution on flower quality of modified atmosphere low temperature (MALT)-stored gladiolus cut spikes. Acta Horticulturae, v.847, p.129-138, 2009. Available from: <http:// dx.doi.org/10.17660/ActaHortic.2009.847.16>. Accessed: Jun. 07, 2017. doi: 10.17660/ActaHortic.2009.847.16.

SRILAONG, V.; BUANONG, M. Effect of chlorophenol and 8-hydroxyquinoline sulphate on vase life of cut rose (Rosa hybrida L.). Acta Horticulturae, v.755, p.445-450, 2007. Available from: $<$ https://doi.org/.10.17660/ActaHortic.2007.755.60>.Accessed: Jun. 07, 2017. doi: 10.17660/ActaHortic.2007.755.60
VAN DOORN, W.G. Water relations of cut flowers. II. Some species of tropical provenance. ActaHorticulturae, v.482, p.65-69, 1999. Available from: <https://doi.org/10.17660/ActaHortic.1999.482.8> Accessed: Jun. 07, 2017. doi:10.17660/ActaHortic.1999.482.8.

VAN DOORN, W. Role of soluble carbohydrate in flower senescence: a survey. Acta Horticulturae, v.543, p.179183, 2001. Available from: <http://dx.doi.org/10.17660/ ActaHortic.2001.543.21>. Accessed: Jun. 07, 2017. doi:10.17660/ ActaHortic.2001.54321.

VAN MEETEREN, U. Causes of quality loss of cut flowers - a critical analysis of postharvest treatments. Acta Horticulturae, v.847, p.27-36, 2009. Available from: <http://dx.doi.org/10.17660/ ActaHortic.2009.847.2>. Accessed: Jun. 07, 2017. doi: 10.17660/ ActaHortic.2009.847.2. 